IZA DP No. 4432

Employment, Wages, and the Economic Cycle: Differences between Immigrants and Natives

Christian Dustmann

Albrecht Glitz

Thorsten Vogel

September 2009 


\title{
Employment, Wages, and the Economic Cycle: Differences between Immigrants and Natives
}

\author{
Christian Dustmann \\ University College London, \\ CReAM and IZA \\ Albrecht Glitz \\ Universitat Pompeu Fabra \\ and IZA \\ Thorsten Vogel \\ Humboldt-Universität zu Berlin
}

Discussion Paper No. 4432
September 2009

IZA

P.O. Box 7240

53072 Bonn

Germany

Phone: +49-228-3894-0

Fax: +49-228-3894-180

E-mail: iza@iza.org

Any opinions expressed here are those of the author(s) and not those of IZA. Research published in this series may include views on policy, but the institute itself takes no institutional policy positions.

The Institute for the Study of Labor (IZA) in Bonn is a local and virtual international research center and a place of communication between science, politics and business. IZA is an independent nonprofit organization supported by Deutsche Post Foundation. The center is associated with the University of Bonn and offers a stimulating research environment through its international network, workshops and conferences, data service, project support, research visits and doctoral program. IZA engages in (i) original and internationally competitive research in all fields of labor economics, (ii) development of policy concepts, and (iii) dissemination of research results and concepts to the interested public.

IZA Discussion Papers often represent preliminary work and are circulated to encourage discussion. Citation of such a paper should account for its provisional character. A revised version may be available directly from the author. 
IZA Discussion Paper No. 4432

September 2009

\section{ABSTRACT}

\section{Employment, Wages, and the Economic Cycle: Differences between Immigrants and Natives}

In this paper, we analyse differences in the cyclical pattern of employment and wages of immigrants and natives for two large immigrant receiving countries, Germany and the UK. We show that, despite large differences in their immigrant populations, there are similar and significant differences in cyclical responses between immigrants and natives in both countries, even conditional on education, age, and location. We decompose changes in outcomes into a secular trend and a business cycle component. We find significantly larger unemployment responses to economic shocks for low-skilled workers relative to high-skilled workers and for immigrants relative to natives within the same skill group. There is little evidence for differential wage responses to economic shocks. We offer three explanations for these findings: an equilibrium search model, where immigrants experience higher job separation rates, a model of dual labour markets, and differences in the complementarity of immigrants and natives to capital.

JEL Classification: E32, F22, J31

Keywords: immigration, unemployment, business cycle

Corresponding author:

Albrecht Glitz

Department of Economics and Business

Universitat Pompeu Fabra

Jaume I Building

Ramon Trias Fargas, 25-27

08005 Barcelona

Spain

E-mail: albrecht.glitz@upf.edu 


\section{Introduction}

In this paper, we investigate the way different immigrant groups respond to the economic cycle compared to native workers. Our analysis distinguishes between immigrants from OECD- and non-OECD countries, and covers two of the largest economies in Europe: Germany and the UK. Both countries have large immigrant populations, which differ in terms of origin composition and educational background. We show that there are large differences in cyclical responses of unemployment between immigrants and natives in both countries. We demonstrate that substantial differences in cyclical patterns remain, even within narrowly defined skill groups. We also show that developments in the relative wage position of immigrants have been quite different in the UK and Germany, in particular over the last decade.

We then estimate a factor-type model that separates responses to economic shocks from a secular trend and allows us to obtain a summary measure for differences across and within education groups. This analysis confirms the larger cyclical response of unemployment for immigrants, in particular for those from non-OECD countries, in both Germany and the UK. Our results are robust to alternative measures of economic shocks, and are not driven by selective in- and out-migration of individuals over the economic cycle.

We provide a number of possible explanations for our findings. First, we consider an equilibrium search model of the type set up by Diamond (1982), Mortensen (1982), and Pissarides (1985). In this model, differences in the hiring intensity between groups in up- and downturns occur if job separation rates differ. We provide evidence for differences in job separation rates between immigrants and natives, even within education groups. Second, we consider a dual labour market. As a third explanation, we investigate the possibility of differences in capital-labour complementarities between groups. We conclude that each of these explanations may contribute to the pattern we observe in our data.

The structure of the paper is as follows. In Section 2, we provide some background information about immigration to Germany and the UK, and economic outcomes and composition of immigrants in the two countries. We then discuss the data we use for our analysis. Section 3 illustrates economic outcomes of different groups of immigrants in both Germany and the UK over the economic cycle, compares these to outcomes of native workers, and investigates how much of these differences are due to differences in education, age, and regional allocation. Section 4 estimates a model that summarises these differences in 
a set of parameters that allows comparisons between groups and across countries. Section 5 hypothesises about possible explanations for our empirical findings.

The differential response of immigrants even within the same skill groups, so far largely overlooked in the economic literature (a notable exception is recent work by Barth et al., 2004, 2006), has important implications for immigration policy as well as for the analysis of the economic impact of immigration and the adaptation process of immigrant groups in their host countries. We discuss these in Section 5.

\section{Background and Data}

\subsection{Migration to Germany and the UK}

Both the UK and Germany experienced large waves of immigration in the period after World War II. The first large wave into Germany was an inflow of ethnic Germans, expelled from former German territory, and totalling 12 million between 1945 and 1949 (see Oezcan, 2004, for details). After 1955, the West German economy grew rapidly and immigration from Italy, Spain, Greece, Turkey, Portugal and Yugoslavia in the late 1950s and early 1960s led to a rise in the number of foreign workers to 2.6 million in 1973, or 12 percent of the total labour force. The period after 1973 was characterised by family re-unification, and the early 1980s saw the arrival of the first larger waves of asylum seekers. Towards the end of the 1980s, and accelerated by the fall of the Berlin wall, Germany experienced a new large immigrant inflow from the East. The two largest groups were ethnic German immigrants (so-called Aussiedler), who migrated from Eastern Europe and beyond, totalling 2.8 million between 1987 and 2001, and migrants from Former Yugoslavia who came as refugees as a result of the Yugoslav wars of the 1990s. In 2002, there were 7.3 million foreign citizens living in Germany, representing 8.9 percent of the total population (German Statistical Office).

Immigration legislation in the UK after World War II, embodied in the 1905 Aliens Act and the 1948 British Nationality Act, distinguished formally between Commonwealth and non-Commonwealth citizens. Immigration of Commonwealth citizens was most pronounced in the two decades after the war. While the early 1950s were characterised by migration from the Caribbean, in the late 1950s a growing number of immigrants arrived from India, and later from Pakistan and Bangladesh. After the 1971 Immigration Act brought an end to the privileged position of Commonwealth citizens, an increasing share of immigration was due to 
family unification, which remained for a time largely unrestricted. Recently, immigration has increased again significantly, mainly as a result of the strong British economy and, after May 2004, the accession of the new EU member states. In 2002, there were 4.9 million foreign born individuals living in the UK, representing 8.3 percent of the total population (British Labour Force Survey, own calculations).

\subsection{Data and Samples}

Our analysis is based on two large longitudinal data sets. For Germany, we use an administrative data set provided by the Institute for Employment Research in Nuremberg (the IABS), which is a 2 percent sample of all dependent employees that are subject to social security contributions. We focus on West Germany, excluding Berlin, due to the differences in wage structure and immigration experience in East Germany and the time span analysed in this study. For the UK, we use the British Labour Force Survey (LFS). The LFS is a survey of private households living in Great Britain, conducted biannually from 1973 to 1983, and annually between 1984 and 1991. Since the spring quarter 1992, the survey is conducted quarterly as a rotating panel, with individuals included in five consecutive waves. Questions on earnings were not asked before the winter quarter of 1992/1993. Both data sets cover approximately the same time period, 1982-2001 for Germany and 1981-2005 for the UK, and are sufficiently large to analyse minority populations. We provide more details on the data in Appendix 1.

For the UK, immigrant status is defined by country of birth. In contrast, official data in Germany distinguish between foreign and German citizenship (following the principle of nationality by descent). In the IABS, therefore, we only observe an individual's citizenship but neither the place of birth nor the year of entry into the country. As an individual born in Germany to foreign parents does not automatically obtain German citizenship, there are some individuals included in our sample who were born in Germany but have foreign citizenship. ${ }^{1}$ On the other hand, individuals who were born abroad but received German citizenship are recorded as Germans in our data. For simplicity, we will in what follows refer to the foreign

\footnotetext{
${ }^{1}$ Between 1993 and 2002, the share of these second generation immigrants in the 25-54 age bracket
} considered in our analysis is small, between 3.5 percent and 7.5 percent (numbers based on tabulations provided by the Statistical Office in Germany). 
sample in the German data as "immigrants" and the German sample as "natives". We will use the same terminology for the foreign born and native born in the UK.

To account for group differences in a parsimonious way that allows comparability across the two countries, we distinguish between immigrants from OECD and non-OECD countries. ${ }^{2}$ We expect immigrants from OECD countries to be endowed with human capital that is more suited to the requirements of the host countries' labour markets. As outcome measures, we focus on unemployment and wages. In Appendix 1 we describe our measures in more detail and discuss comparability.

\subsubsection{Composition of Immigrant Populations}

Reflecting the different migration histories of Germany and the UK, the composition of the immigrant populations over the last two decades differs considerably between the two countries. While the overall immigrant share in the age group 25-54 decreased in Germany from 10.8 percent in 1981 to 8.6 percent in 2001, it increased from 8.4 percent to 10.4 percent in the UK over the same period. In Germany, about 27 percent of the immigrant population in 1981 originates from a non-OECD country; by 2001, this share has increased to about 33 percent. In the UK, about 58 percent of all immigrants originate from a non-OECD country in 1981, and this fraction increases to about 64 percent in 2001. Breaking down the data by origin shows that while for Germany the largest OECD group in 2001 is Turkish (42 percent of all OECD immigrants), it is Irish for the UK (20 percent of all OECD immigrants). Immigrants from India and Pakistan make up most of the non-OECD group in the UK in 2001 (together 24 percent of all non-OECD immigrants), while it is immigrants from Former Yugoslavia in Germany (44 percent of all non-OECD immigrants).

\subsubsection{Individual Characteristics}

In Table 1, we report some characteristics for natives and immigrants for the year 2001. For Germany, we distinguish between three educational levels: Individuals who have no postsecondary education (low education); individuals who have post-secondary vocational

2 Current OECD member countries are Austria, Belgium, Denmark, Finland, France, Germany, Greece, Iceland, Ireland, Italy, Luxembourg, Netherlands, Norway, Poland, Portugal, Spain, Sweden, Switzerland, Australia, Japan, Korea, Mexico, New Zealand, United States, Canada, the Czech Republic, Hungary, Slovakia, Poland, and Turkey. 
training (intermediate education); and individuals who have university education (high education). Similar to the classification for Germany, for the UK, the low education group refers to individuals without any post-secondary education. As intermediate education we code GCE A Level or equivalent, GCSE grades A*-C or equivalent and other qualifications. The high education group comprises individuals holding a university degree or other higher education qualifications.

The figures in Table 1 show that the percentage of college graduates among natives in Germany is far lower than in the UK. This is due to the fact that a large part of professional training that is offered by colleges in the UK is offered by the apprenticeship system in Germany. While in Germany the share of college-educated individuals is substantially lower in the immigrant than in the native population, in the UK the share of those with a college education is higher for both OECD and non-OECD immigrants. Overall, and in comparison to natives, immigrants in the UK are considerably better educated than they are in Germany.

Mean log real wages for both men and women are significantly lower among immigrants in Germany, with a particular disadvantage for those who come from non-OECD countries. In the UK, wages are higher for each immigrant group, except non-OECD men. The wage rates of immigrants from OECD countries are particularly remarkable. Men and women earn on average 19 and 22 percent higher wages than their native counterparts, respectively. Finally, in both Germany and the UK, unemployment rates of immigrants, with the exception of OECD men in the UK, are considerably higher than those of natives.

In the bottom row of Table 1 we present the normalised Herfindahl index to measure regional concentration of natives and immigrants. ${ }^{3}$ This index is bound between zero (individuals are equally distributed across regions) and one (complete concentration in one region). For Germany, the index is 0.08 for natives and 0.11 for immigrants, suggesting that immigrants are not particularly concentrated relative to the native population. This is in stark contrast to the UK. Here the index is 0.02 for natives and 0.15 for immigrants, suggesting a much stronger regional concentration, particularly so for immigrants from non-OECD

${ }^{3}$ The index is defined as $H=\left(\sum_{i}^{N} s_{i}{ }^{2}-1 / N\right) /(1-(1 / N))$, where $s_{i}$ is the share of individuals, either natives, OECD or non-OECD immigrants, living in region $i$, and $N$ is the overall number of regions. 
countries. This is largely due to about 40 percent of non-OECD immigrants living in London, compared to only 8 percent of the native born.

To summarise, it appears that the composition of the immigrant populations in Germany and the UK differs considerably with respect to origin. Furthermore, immigrants are, relative to natives, far better educated in the UK, and earn higher wages. In both countries, immigrants tend to experience higher unemployment rates than natives.

\section{Economic Outcomes and the Economic Cycle}

\subsection{Macroeconomic Conditions}

Over the last three decades, macroeconomic conditions have changed in both countries in roughly similar ways (see Figure 1). For instance, according to GDP growth (based on data provided by the Statistical Office for Germany and the OECD for the UK), recessions in Germany and the UK occur largely simultaneously. This is particularly the case for the recessions of the mid 1970s (dated by the CEPR Business Cycle Dating Committee to last from 1974q3 to 1975q1) and early 1980s (1980q1-1982q3). In the latest major recession of the early 1990s, the German economy (1992q1-1993q3) was hit about 1 year later than the UK, due to German re-unification. As also shown in Figure 1, both Germany and the UK experienced considerable increases in unemployment in the early-mid 1980s recession, with some improvement towards the end of the decade. The early 1990s recession led again to an increase in unemployment in both countries. However, while unemployment figures started coming down shortly after this recession in the UK, this was not the case for Germany where unemployment continued to rise throughout the decade, with a small temporary decrease towards the end of the 1990s/early 2000s. Since the recession of the early 1990s, the British economy has grown at a steady pace of approximately 3.1 percent per year in real terms, and the unemployment rate has continuously declined to a level of less than 5 percent in 2005 . In West Germany, unemployment has increased substantially over the period, reaching about 8 percent in 2005. Furthermore economic growth was sluggish with an average annual growth rate of only about 0.7 percent between 1995 and 2005. 


\subsection{Unemployment and Wages over the Economic Cycle}

\subsubsection{Unemployment}

We now turn to unemployment rate differentials between natives and immigrants from OECD and non-OECD countries for Germany and the UK. As some of these differences may be explained by differences in observable characteristics, we condition on educational attainment, age structure, and regional allocation. We estimate the following model, choosing the native German and UK populations as the reference groups:

$$
y_{i t}^{g}=X_{i t}^{g} \alpha+\sum_{\substack{g=O E C D, \\ \text { Non-OECD }}} \sum_{t=t_{1}}^{T} \gamma_{t}^{g} T_{t}^{g}+\sum_{t=t_{1}}^{T} \gamma_{t} d_{t}+e_{i t}^{g}
$$

where $y_{i t}^{g}$ is the outcome for individual $i$ belonging to group $g$ (natives, OECD immigrants, non-OECD immigrants) in period $t, X_{i t}^{g}$ is a vector of additional controls such as gender, education, age, etc., and $e_{i t}^{g}$ is an error term. The variables $d_{t}$ are year dummies for each year $t$, and the $T_{t}^{g}$ represent the interactions of the group indicator $g$ with the year dummies. The estimated parameters $\gamma_{t}^{g}$ are the group mean labour market outcomes of OECD/non-OECD immigrants relative to the native population (picked up by $\gamma_{t}$ ) conditional on variables included in $X_{i t}^{g}$. By sequentially adding age, age squared and interactions of our education groups and year dummies (dashed line), and interactions of region and year dummies (dotted line), we eliminate differences in estimates of economic outcomes between groups that may be due to differences in these observable characteristics. We plot the resulting estimates of $\gamma_{t}^{g}$ in Figure 2.

We first focus on the solid lines that depict differentials that condition on gender only. At the start of the 1980s, unemployment rates in Germany were very similar for natives and the two groups of immigrants. The 1980s recession led to a larger increase in unemployment for immigrants, but in the subsequent recovery phase unemployment also dropped faster for the two immigrant groups, closing the unemployment gap. In the 1990s recession, unemployment again grew considerably faster for immigrants than it did for natives, leading to a dramatic increase in the unemployment rate differential between both groups of immigrants and natives at the height of the recession. Towards the end of the 1990s, unemployment of immigrants seemed again to drop more rapidly than unemployment of natives but, compared to the early 
1980s, there remained a sizeable difference between the two immigrant groups and natives. The figures thus suggest a strong cyclical development in unemployment differences between immigrants and natives.

For the UK, the solid line in the lower panel of Figure 2 shows a positive unemployment rate differential between immigrants from non-OECD countries and natives as early as 1981 . Unemployment for OECD immigrants on the other hand was similar to that of natives. As in Germany, the 1980s recession had a larger impact on non-OECD immigrants: the unemployment rate differential increases substantially, but decreases again rapidly in the subsequent recovery phase. The early 1990s recession saw unemployment of immigrants rising once more considerably faster than unemployment of natives, and in particular so for non-OECD immigrants. After the end of the recession, the unemployment rate differentials decreased yet again. Overall, the figures for the UK suggest a similar pattern in the difference in unemployment rates as in Germany, with a somewhat more pronounced cyclicality for nonOECD immigrants than for OECD immigrants.

The dashed line in the upper panel of Figure 2 suggests that conditioning on age and education reduces the unemployment differential between Germans and immigrants in both groups; however, the differences in the cyclical pattern remain. Conditioning further on regional allocation does not lead to significant changes in the conditional unemployment rate differentials. The differences between the conditional and unconditional patterns in the UK, shown in the lower panel of Figure 2, are smaller than in Germany. This is not surprising, as the age and education structure of immigrants in the UK resembles that of the native population more closely, as shown in Table 1. However, as for Germany, we still see a clear cyclical pattern in unemployment rate differentials in the early 1980s and 1990s, particularly pronounced for non-OECD immigrants.

\subsubsection{Wages}

Figure 3 displays log wage differentials for Germany and the UK, where the solid line conditions on gender only. For Germany there is a wage differential of about 8-9 percent in favour of native workers relative to both groups of immigrants in 1980. During the first recession, this wage differential remained fairly constant, but it increased dramatically from the early 1990s onwards, in particular for non-OECD immigrants. As in the case of unemployment, there is a reduction in the differential between the two immigrant groups and natives when we condition on age, education and regional allocation, suggesting that part of 
the differential is due to composition. However, after 1990, controlling for differences in observable characteristics can only account for around one third of the widening wage gap between natives and non-OECD immigrants, still leaving a gap of more than 15 percent unexplained by 2000. The conditional wage gap between natives and OECD immigrants, while being close to zero throughout the 1980 s, stabilises at about 5 percent throughout the 1990s. In the lower panel of Figure 3, we display the conditional log wage differentials for the UK. Here we only have wage information after 1991. The difference to Germany is quite striking. Conditioning on age and education does not affect the differential between natives and OECD immigrants; it does, however, turn the differential between non-OECD immigrants and natives negative. This is the opposite of what we find for Germany, and suggests that non-OECD immigrants would worsen their relative wage position in comparison to natives if they had the same age and education structure. The slight overall wage advantage of non-OECD immigrants turns into a substantial disadvantage when keeping individual characteristics the same. Moreover, the wage differential relative to natives worsens further when we condition on region dummies, which is due to an over-representation of immigrants in high-wage London. As opposed to Germany, there is no deterioration in relative wages for immigrants in the UK between 1992 and 2005.

To sum up, our findings suggest that for both Germany and the UK, unemployment probabilities of immigrants are more sensitive to the economic cycle than those of natives. Conditioning on individual characteristics and regional allocation reduces this differential slightly in the case of Germany, but the stronger pro-cyclical pattern for immigrants remains. For wages, there is not much evidence for cyclical differentials either in Germany or the UK. While in the UK relative wages of immigrants did not change much over the observation period, there seems to be a long-term gradual deterioration of the relative wage position of immigrants in Germany, in particular since the early 1990s.

\section{Differential Responses to Economic Shocks across Groups}

\subsection{The Model}

We now estimate a more structural model to summarise the evidence we have provided so far and to quantify the differential response of different skill groups, and of natives and 
immigrants within the same skill group. The idea of our approach is similar to Hoynes (2000). We utilise differences in economic shocks across regions and over time to identify the relative response of different education and population groups to such shocks, conditional on region effects, age effects, and a group-specific time trend. Our outcome variables are unemployment rates and log wages. The model allows us to assess the magnitude by which outcomes of the groups react differently to economic shocks, and to test whether these differences are statistically significant.

More formally, consider the following outcome equation:

$$
y_{j r t}^{g}=a_{j}^{g}+b_{j}^{g} t+c_{j}^{g} f_{r t}+\sum_{a=2}^{6} \delta_{a}^{g} \times S_{a j r t}^{g}+\mu_{r}+v_{j r t}
$$

where $y_{j r t}^{g}$ is the labour market outcome (unemployment rates or average log wages) of skill group $j$ (defined by education and gender) in region $r$ in time period $t$. The index $g$ distinguishes between natives, OECD- and non-OECD immigrants. The skill-specific labour market outcome is a function of a fixed group and skill effect $a_{j}^{g}$, a group and skill-specific time trend $b_{j}^{g}$, six age group shares $S_{\text {ajrt }}^{g}$, a fixed region effect $\mu_{r}$, and a measure of the region-specific business cycle effect $f_{r t}$. The common factor $f_{r t}$ is assumed to be identical for all skill and immigrant groups. The coefficient $c_{j}^{g}$ measures the responsiveness of group $g$ with skill level $j$ to business cycle fluctuations, as captured by the common factor $f_{r t}$. This econometric model is flexible in that we allow for as many independent common factors as there are regions and only assume that the group- and skill-specific coefficients are identical across regions (and of course time). Moreover, we do not impose any restrictions on these factors. For example, if there are 11 regions and 12 time periods, then there are 132 unobserved common factors.

To eliminate fixed group, skill and region effects, we estimate the above equation in first differences:

$$
\Delta y_{j r t}^{g}=b_{j}^{g}+c_{j}^{g} \Delta f_{r t}+\sum_{a=2}^{6} \delta_{a}^{g} \times \Delta S_{a j r t}^{g}+\Delta v_{j r t} .
$$

Possible measures for business cycle shocks could be the overall region-specific unemployment rate or the regional GDP (growth). However, these measures are likely to pick up only part of the shock that hits a particular region. Furthermore, it is not clear whether an 
appropriate measure for a shock that impacts on employment and wages are current or past changes, or combinations thereof. We therefore estimate shocks $\Delta f_{r t}$ as the parameter on the interaction term of year $t$ and region $r, T_{r t}$. Denote these parameters as $\beta_{r t}$. Our final estimation model is then given by: ${ }^{4}$

$$
\Delta y_{j r t}^{g}=b_{j}^{g}+c_{j}^{g} \beta_{r t} T_{r t}+\sum_{a=2}^{6} \delta_{a}^{g} \times \Delta S_{a j r t}^{g}+\Delta v_{j r t}
$$

In this model, identification of parameters $b_{j}^{g}$ and $c_{j}^{g}$ is obtained by assuming that the labour market-specific shocks $\beta_{r t}$ are identical for all groups $g$ and skill levels $j$. Both sets of parameters need to be normalised. We set $c_{j}^{g}$ equal to one and $b_{j}^{g}$ equal to zero for the base group, which we choose to be native male workers with university education for Germany and native male workers with a university degree or other higher education qualification for the UK. The reported estimates of $c_{j}^{g}$ measure the deviations of the outcome $y_{j r t}^{g}$ from its longterm trend, relative to the reference group.

If the differential response to the economic cycle, as illustrated in Section 3.2, was only due to different skill compositions of the native and the immigrant population, then for a given skill group $j$, the parameter $c_{j}^{g}$ should be the same for immigrants and natives.

\subsection{Estimation Results}

Table 2 reports results of Eq. (1) for Germany and the UK. Our focus in this section is on men. For completeness we report results for women in Appendix 2, Table A1. For the UK, we pool 2 subsequent years in order to obtain a sufficient number of observations within skilland origin group for each of the $11 \mathrm{UK}$ regions. We report the estimated parameters $c_{j}^{g}$ for the unemployment rates for each of our 9 groups (3 education x 3 nationality/origin) for Germany and the UK in columns (1) and (2), and the corresponding parameters for wages in columns (3) and (4). We report the standard errors underneath the coefficient estimates where

${ }^{4}$ This model can be seen as a special case of a strict factor model, setting the first common factor equal to unity. Such a strict factor model in turn is a special case of a dynamic factor model as set out, for instance, in Forni et al. (2000), in which there is an additional set of lagged common factors (see also Breitung and Eickmeier, 2006; Lütkepohl, 2006, Ch. 18.2). 
asterisks $(*)$ are used to indicate that a coefficient is statistically different from one (the parameter of the base group) at the 5 percent level. We also test the hypothesis that responses of the two immigrant groups are different from those of native workers within the same skill group. Significant differences in estimates at the 5 percent level are in this case marked with a cross (+).

For both Germany and the UK, the estimates reported in columns (1) and (2) of Table 2 show that the unemployment rates of low-educated individuals fluctuate stronger over the business cycle than the unemployment rates of the highly educated. For natives in Germany, for instance, the estimate increases from 1 for the reference group with college education to 2.4 for the group with intermediate education, and to 4.5 for the group with a low education level. This indicates that the response of the unemployment rate of low-educated men to macroeconomic shocks is stronger by factor 4.5 than the response of highly educated men. The estimates for the UK are remarkably similar in magnitude.

Within skill groups, immigrants appear to be far more responsive to the cycle than natives. While natives with intermediate education in Germany respond 2.4 times stronger to business cycle shocks than natives with college education, OECD immigrants react 4.2 times stronger and non-OECD immigrants 5.7 times stronger. Within the group of low-educated individuals, the responsiveness of OECD immigrants to shocks is similar to that of natives, but the responsiveness of non-OECD immigrants is substantially stronger, with a point estimate of 6.7 .

For the UK, natives and OECD immigrants with intermediate education react similarly to shocks with an estimate of around 2.9, but non-OECD immigrants react significantly stronger than both of these groups, with a point estimate of 4.2. Within the group of low-educated individuals, point estimates suggest again that both groups of immigrants respond stronger than their native counterparts (5.1 and 5.5, respectively, compared to 3.9 for natives) although the estimated differences between groups are not statistically significant.

For women the results in Table A1 in Appendix 2 confirm the overall pattern that we find for men, though with somewhat smaller differences across skill groups. As for men, immigrants tend to react stronger to economic shocks than natives, with OECD immigrants in Germany and non-OECD immigrants in the UK appearing to be particularly sensitive.

We now turn to wages, and we report results in the last two columns of Table 2. For Germany the numbers in column (3) suggest that the wage fluctuations over the business 
cycle are somewhat larger for native men with intermediate and low levels of education, compared to the highly educated. Within skill groups, though, we only find statistically significant differences in the responsiveness of wages to economic shocks for mediumeducated OECD immigrants and low-educated non-OECD immigrants. In both cases immigrants' wages are less responsive than wages of comparable natives. This may be explained by the stronger responsiveness of immigrant employment, which may result in more selection into and out of unemployment.

Results for wages of men in the UK are displayed in column (4) of Table 2. There seem to be no clear differences across skill groups in the response to economic shocks. As for Germany, there is also little evidence of a differential response to economic shocks between immigrants and natives within skill categories. Only the estimate for non-OECD immigrants with intermediate education is significantly higher than that for natives.

For women, results are reported in columns (3) and (4) of Table A1 in Appendix 2. The reference group continues to be highly educated men. For both countries, and similar to men, there is little evidence of large differences between immigrants and natives within skill groups.

To summarise, we find sizeable and statistically significant differences between immigrants and natives in their unemployment response within education groups. These differences are particularly pronounced for immigrants from non-OECD countries. On the other hand, there is little evidence of differential responses of immigrants and natives in terms of wages. Next, we will investigate whether our findings are explained by cyclical in- and outmigration, and whether they are robust to alternative measures for the business cycle. We will also analyse whether responses are symmetric in economic up- and downturns.

\subsection{Extensions}

\subsubsection{Cyclical In- and Out-migration}

One explanation for the strong cyclical behaviour of immigrants' unemployment rates may be selective in- or out-migration. For instance, if entry of immigrants is driven by the economic cycle, so that immigrants are drawn to Germany and the UK during expansions, one may expect to see the unemployment rate for immigrants fall faster than for natives (since new immigrants are likely to come with a job, essentially adding an employed person to the 
denominator of the unemployment rate). Self-selection of immigrants into regions that offer the highest wages and lowest unemployment rates has been documented by a number of studies (see, for instance, Borjas 2001, and, more recently, Jaeger 2007). One way to address this is to use a balanced panel and examine how individuals who have already been living in the country in some base period perform over the business cycle. For Germany, we thus reestimate our model, restricting the immigrant sample to those immigrants that we observe in the data in 1982. For the UK, we restrict the sample to those foreign born individuals that report having immigrated in or before 1981.

We report results for unemployment for men in columns (1) and (2) of Table 3. Although typically smaller in magnitude and less precisely estimated, the parameter estimates of $c_{j}^{g}$ show the same pattern as those we report in Table 2. The responsiveness to economic shocks increases with lower educational attainment. Both OECD and non-OECD immigrants react more strongly than their native counterparts, with the exception of low-educated OECD immigrants in Germany who now show less responsiveness than comparable native workers. Thus, the cyclical response we observe seems not to be driven by in-migration reacting to the economic cycle. ${ }^{5}$

\subsubsection{Business Cycle Measures}

So far, we have modelled business cycle effects as an unobserved region- and timespecific factor. As explained earlier, we believe that this captures all the relevant influences on unemployment variations across groups. We now check whether the results are similar when we use an alternative measure for the economic cycle. One such measure is the regionspecific deviation of GDP growth from its trend. We use the Hodrick-Prescott filter to obtain a decomposition of GDP into a trend component and a cyclical component. We then replace the nonlinear term of the unobserved factor $\left(c_{j}^{g} \beta_{r t} T_{r t}\right)$ in Eq. (1) with the interactions of the education/nationality groups and the cyclical component of the HP-filtered GDP time series

${ }^{5}$ Due to its longitudinal nature, the data for Germany also allow us to check whether our findings are due to selective out-migration by further restricting the immigrant sample to those individuals that we observe both in the base period 1982 and in the final period 2001. The general pattern across and within education groups that we report in Table 2 still persists even in this very restricted sample. 
for each region. ${ }^{6}$ In columns (3) and (4) of Table 3 we report the results for Germany and the UK. The estimated coefficients are very similar to those we obtain earlier. Using measures for business cycle shocks that are conventionally used in macroeconomics, we thus reach similar conclusions to those we discussed above.

\subsubsection{Asymmetric Unemployment Response}

So far, we assume the differential response of immigrants and natives to be symmetric in economic upturns and downturns. This may be too strong an assumption. In Section 5, we discuss a number of different theoretical explanations, which suggest that this differential response is not necessarily symmetric. To investigate this issue, we re-estimate our models, allowing for different responses during periods of economic expansion and contraction. As this requires us to determine when a recession or a boom period begins, this harbours a certain degree of arbitrariness. Based on the macroeconomic indicators in Figure 1, we define the years of an economic downturn for Germany to be 1982-1983 and 1993-1997, and for the UK 1981-1986 and 1991-1992.

Table 4 reports the results. Columns (1) and (3) show the group-specific effects in economic upturns, and columns (2) and (4) show the difference in group-specific effects between economic downturns and economic upturns. The estimates in columns (1) and (2) provide no evidence for differences in cyclical responses in boom and bust periods in Germany: none of the parameter estimates in column (2) is significantly different from zero. In the UK the pattern is somewhat different: there is some evidence that during an economic contraction the low-educated individuals (and, to some degree, those with intermediate education) react less strongly relative to the reference group of native high-skilled men than during an economic expansion. The responsiveness of both OECD and non-OECD immigrants with low education and comparable natives during an economic downturn is quite similar, with parameter estimates of 2.407 (calculated by the sum of the corresponding parameters in columns (3) and (4)), 4.532 and 2.935, respectively. Accordingly, while the results for Germany suggest roughly symmetric responses - immigrants lose jobs faster in

\footnotetext{
${ }^{6}$ Regional GDP data on German regions ("Länder”) were obtained from the Volkswirtschaftliche
} Gesamtrechnung der Länder, and UK regional GDP data from National Statistics UK. All GDP time series are adjusted using time series of the corresponding consumer price index. Following Ravn and Uhlig (2002), we choose $\lambda=6.25$ when filtering the GDP time series. 
downturns, but gain jobs faster in upturns - the results for the UK point towards asymmetric responses. Differential adjustments both across and within skill groups seem to primarily take place during periods of economic expansion. During periods of economic contraction, the responsiveness across and within groups is more homogenous.

\section{Explaining Differences in Cyclical Responses}

From our empirical investigation the following three findings stand out: First, the cyclicality of unemployment rates is the stronger, the lower the educational qualification of workers. Second, within education groups the cyclicality in unemployment is stronger for immigrants than for natives, and strongest for non-OECD immigrants. And third, the difference in cyclicality between natives and immigrants seems to be symmetric in Germany immigrants lose jobs faster or remain longer unemployed in downturns, but get back to employment faster in upturns - but asymmetric in the UK. Here a stronger responsiveness of immigrants appears to be present predominantly in periods of economic expansion. In addition, wages are generally found to be unresponsive to the business cycle. In this section we discuss three possible explanations for the differential cyclical responses of unemployment rates.

\subsection{Equilibrium Search}

Our first explanation builds on a standard DMP equilibrium search model, a line of research originating in the work of Diamond (1982), Mortensen (1982), and Pissarides (1985). In DMP models unemployment is due to search frictions. In the simplest set-up, which we consider here, established matches break up at a given rate that is constant over the business cycle. ${ }^{7}$ Hiring of workers by firms depends on whether firms and workers can find suitable matches, which in turn depends on the profitability of opening (costly) vacancies. The higher the pay-off for opening a vacancy, the more vacancies are created and the higher is the number of established matches. Over the business cycle expected pay-offs of vacancies fluctuate with labour productivity and so does hiring of workers and hence the unemployment rate. For the present purpose, the crucial insight is that the higher the group-specific

\footnotetext{
${ }^{7}$ For an excellent overview of the debate in this literature on this assumption, see Yashiv (2007).
} 
separation rate, the stronger the volatility of expected pay-offs, implying greater fluctuations in the number of created vacancies and hence jobs.

The basic intuition for this result is the following. The longer a worker is expected to stay with the firm (i.e., the lower the separation rate), the greater is the impact of his productivity in the more distant future for the firm's value of the match. That is, the lower the separation rate, the less important becomes the worker's current productivity and the more important becomes the impact of the worker's average productivity for the firm's investment decision (opening of vacancies). By contrast, the higher the separation rate, the more closely firms follow the business cycle and the more pro-cyclical is their offer of vacancies. The differential response to business cycle shocks of different labour types with identical labour productivity in this model is thus driven by different levels of (time-invariant) separation rates. For our analysis, if within education groups, immigrants are more likely to leave a job earlier, then fewer vacancies will be made available for them in a recession, thus increasing their unemployment relative to natives. On the other hand, in a boom phase relatively more vacancies will be created that are to be filled with immigrant workers. Thus, in this model neutral macroeconomic shocks, affecting the productivity of the different types of labour symmetrically, are transmitted into asymmetrically strong cycles of unemployment rates. In Appendix 3 we provide a more formal exposition of this argument.

Whether immigrants have lower or higher separation rates in jobs is empirically testable. With our data, we can compute overall survival probabilities within jobs for Germany, as we can follow individuals over time. In Panel A of Table 5, we display Kaplan-Meier survival probabilities for men, distinguishing between different education groups and between natives and the two groups of immigrants. The figures show that survival probabilities are lower for both groups of immigrants at each year of firm tenure. There is also some evidence that the survival probabilities fall with decreasing educational attainment of workers. To eliminate differences due to the economic cycle and age composition, we estimate Cox proportional hazard models for the two immigrant groups relative to native workers. The estimates, stratified by age group and year, are displayed in Panel B of Table 5. They show that the hazard rates of leaving employment of male immigrants are typically higher than those of natives within each education group, and that the difference tends to be larger for non-OECD immigrants. Interestingly, in the one case in which the hazard rate does not differ from the one of comparable natives (OECD immigrants with low education) we also do not find a differential responsiveness to economic shocks in our results in Table 2. 
These findings are compatible with the hypothesis that differences in separation rates within education groups may be partly responsible for the different cyclical response of natives and immigrants through the equilibrium search mechanism explained above. But what could be a cause for possible differences in separation rates between the two immigrant groups and natives? One reason is return migration. Immigrants have a higher probability to leave the labour market as they may return to their home countries. This would inevitably lead to a termination of the employment relationship. There is evidence that return propensities may be substantial. For instance, for the UK, Dustmann and Weiss (2007) show that after about 5 years in the country, more than 40 percent of all immigrants have returned back home. Mayr and Peri (2008) show that in the U.S. the return migration rate of even those that stayed at least 1 to 4 years amounts to around 20 percent. A recent OECD publication (OECD 2008, Table III.1) reports similar out-migration rates for other countries: The average outmigration rate after 5 years ranges from 28 percent for the Netherlands to 60 percent for Ireland.

\subsection{Dual Labour Markets}

Our second explanation builds on a dual labour market model similar to that discussed in Bulow and Summers (1986). In their standard framework, there is a homogenous group of workers and two types of jobs, primary and secondary jobs, that differ in their monitoring technology. In primary jobs monitoring costs are high and firms therefore have to pay workers higher wages in order to prevent shirking. In secondary jobs monitoring costs are low. As a consequence, secondary jobs can be filled at relatively low costs and hence wages paid in these jobs follow closely marginal labour productivity. Differences in monitoring costs therefore lead to a two-tier labour market with workers in the primary sector having more secure and better paid jobs than workers in the secondary sector. In particular, due to the different adjustment costs in primary and secondary sectors, neutral productivity shocks have asymmetric effects on employment in both sectors. ${ }^{8}$

\footnotetext{
${ }^{8}$ When reducing their labour force, firms in the primary sector have to pay the remaining workers higher wages, as primary workers in firms that announce to lay off workers in the future would shirk if their wages were kept at the pre-announcement rates. Downsizing in firms in the primary sector hence leads to increases in wages of those workers who stay. As firms in the primary sector face relatively high costs when adjusting their labour force due to productivity shocks, swings in labour demand for primary workers are
} 
In an extension of this model, Bulow and Summers (1986) also show that if there are two types of workers differing only in their propensity to leave their jobs (immigrants and natives), then competition among firms ensures that in equilibrium a higher proportion of the type of labour with the higher turnover rate (immigrants) is confined to the secondary sector. The reason for this is that in equilibrium within each sector both types of labour are paid the same wage but, all else equal, in order to induce the same effort of both types of workers, wages would have to be higher for workers with relatively high turnover (immigrants). In equilibrium, chances of moving to the primary sector must therefore be smaller for secondarysector workers with high turnover rates. Thus, although immigrants are equally productive, in equilibrium they are more often employed in the secondary sector, where labour demand follows more closely total factor productivity over the economic cycle because of lower labour adjustment costs. Given some stickiness of secondary-sector wages, which is assumed to be identical for natives and immigrants, employment of immigrants should therefore be more volatile than employment of natives.

\subsection{Capital-skill Complementarity}

Our last explanation builds on capital-skill complementarity (Griliches, 1969, Krusell et al., 2000, Funk and Vogel, 2004). The main assumption here is that there is a fixed factor, say physical capital, which enters asymmetrically into the production function of the firm. Symmetric productivity shocks (neutral shocks to total factor productivity) then result in asymmetric shifts of the labour demand curves of different types of labour. If wages are somewhat sticky, the asymmetric complementarity of the different labour types with capital results in asymmetric effects on unemployment, even when productivity shocks are neutral.

Suppose that wages of all labour types are equally sticky, and capital is fixed. If the degree to which the various labour types can be substituted by capital is not equal for all labour types, then adjustments of employment will be stronger for labour types that are better substitutes for capital. During downturns firms want to reduce all factor inputs but, by assumption, capital stocks cannot be adjusted. Therefore, firms reduce their demand more for those factors that are the closest substitutes for capital. By contrast, during upturns firms want to increase all factor inputs. However, since capital inputs are fixed they hire in particular 
those workers that are the closest substitutes for capital. The argument extends to immigrants and natives within skill groups if immigrants are less complementary to capital than natives. This could be the case if immigrants cannot realise the full return to their observable skills due to, for instance, a lack of language proficiency, preventing them to work in jobs that are more complementary to capital.

We investigate this possibility using data provided by the Federal Institute for Vocational Education and Training (BIBB) on task content and computer use of 11,688 workers in Germany in 1997. Estimating a set of linear probability models, we find that, conditional on educational attainment, immigrants have a 17 percentage point lower probability of working with a computer, a 5 percentage point lower probability of performing analytical tasks, and a 7 percentage point higher probability of performing routine manual tasks than native workers. This is compatible with the hypothesis that, within skill groups, immigrants are less complementary to capital.

\section{Discussion and Conclusions}

Our results suggest larger unemployment responses to economic shocks for immigrants relative to natives within skill groups. These differences are particularly pronounced for nonOECD immigrants, and evident for both Germany and the UK, despite their rather different immigrant populations. We find little evidence in both countries that wage responses of immigrants to shocks are different than those of natives within skill groups. We show that our results are not driven by selective in- and out-migration of immigrants, or by the way we identify region-specific shocks.

We offer three explanations for these findings. First, within an equilibrium search model, immigrants' unemployment may react stronger to the economic cycle if they are experiencing higher job separation rates. We show that job survival rates of immigrants are systematically lower and separation rates are higher, even within skill groups. Second, within a model of dual labour markets, immigrants could be overrepresented in the secondary sector due to their higher job separation rates. Again, this would imply higher volatility in their unemployment experience over the economic cycle. And finally, if immigrants are less complementary to capital than natives and wages are somewhat sticky, this would also lead to the cyclical response we observe. Compatible with this, we demonstrate that immigrants in Germany are 
(conditional on education) less likely to work in jobs that use computers, more likely to perform tasks that are routine, and less likely to perform tasks that are analytical.

Our analysis has implications for other areas of research on immigration. In the literature on the economic assimilation of immigrants, ${ }^{9}$ identification of cohort effects is often achieved by assuming that immigrants and natives react to macro shocks in the same way (see e.g. Borjas, 1999). In two recent papers, Barth et al. $(2004,2006)$ point out that differences in the response to macroeconomic conditions between immigrants and natives invalidate this assumption. As an alternative identification strategy, they propose to parameterise time effects as a function of local labour market conditions and allow these to vary between immigrants and natives. The findings in this paper support their approach.

Our analysis adds a further concern. The strong cyclical pattern in the difference in unemployment rates between immigrants and natives within skill groups may lead to differential selection into work over the economic cycle. To test this we use our German data for the period 1982 to 2001 and regress separately for each nationality/gender group log wages on the interaction of educational attainment and an indicator variable that takes the value one if the individual will be unemployed in the next period. Additional controls include age and age squared, educational attainment, and a set of year and region fixed effects. The results show that those workers who become unemployed in the next period earn around 1525 percent lower wages, compared to workers who remain in employment, which points towards negative selection into unemployment. As immigrants react stronger to adverse business cycle shocks, those immigrants in work in economic downturns may be more positively selected, compared to natives. This may lead to a bias in immigrants' estimated assimilation profiles. ${ }^{10}$ The sign and magnitude of the bias will depend on the cyclicality of the period that is considered, and the differences in response of the individual groups.

\footnotetext{
${ }^{9}$ See, for instance, Borjas (1995) for the US, Baker and Benjamin (1994) for Canada, Edin et al. (2000)
} for Sweden, or Bell (1997) for the UK; for papers investigating immigrants' employment and unemployment dynamics see, for instance, Chiswick et al. (1997) for the US, Wheatley Price (2001) for the UK, or Husted et al. (2001) for Denmark.

${ }^{10}$ As noted above, selection may also explain why our point estimates of the responsiveness of immigrant wages to the economic cycle in Germany (reported in Table 2) tend to be slightly smaller in magnitude for some groups than those of comparable native workers. 
The results in this paper also contribute to the more recent literature on the impact of immigration on wages of native workers. Ottaviano and Peri (2006) argue that, even within age and education cells, immigrants and natives may not be perfect substitutes, as is typically assumed. They test this hypothesis estimating the parameters of a three level CES production function and find indeed evidence for imperfect substitutability of immigrants and natives within quite narrowly defined age and education cells. Card (2009), Manacorda et al. (2006) and D'Amuri et al. (2008) come to similar conclusions in separate analyses for the US, the UK and Germany. Our findings of different unemployment responses of immigrants and natives over the economic cycle point in the same direction and suggest that within the same skill group, immigrants and natives may not be perfect substitutes. 


\section{References}

Baker, M., Benjamin, D., 1994. The performance of immigrants in the Canadian labour market. Journal of Labor Economics 12, 369-405.

Barth, E., Bratsberg, B., Raaum, O., 2004. Identifying earnings assimilation of immigrants under changing macroeconomic conditions. Scandinavian Journal of Economics 106 (1), 122.

Barth, E., Bratsberg, B., Raaum, O., 2006. Local unemployment and the relative wages of immigrants: evidence from the Current Population Surveys. Review of Economics and Statistics 88 (2), 243-263.

Bell, B.D., 1997. The performance of immigrants in the United Kingdom: evidence from the GHS. Economic Journal 107 (441), 333-344.

Bender, S., Haas, A., Klose, C., 2000. The IAB employment subsample 1975-1995: opportunities for analysis provided by the anonymised subsample. Journal of Applied Social Science Studies 120, 649-662.

Borjas, G.J., 1995. Assimilation and changes in cohort quality revisited: what happened to immigrant earnings in the 1980s? Journal of Labor Economics 13 (2), 201-245.

Borjas, G.J., 1999. The economic analysis of immigration. In: Ashenfelter, O., Card, D. (Eds.), Handbook of Labor Economics, vol. 3 (28). Elsevier, pp. 1697-1760.

Borjas, G.J., 2001. Does immigration grease the wheels of the labor market? Brookings Papers on Economic Activity 2001 (1), 69-119.

Breitung, J., Eickmeier, S., 2006. Dynamic factor models. Allgemeines Statistisches Archiv $90,27-42$.

Bulow, J.I., Summers, L.H., 1986. A theory of dual labor markets with application to industrial policy, discrimination, and Keynesian unemployment. Journal of Labor Economics 4 (3), 376-414.

Bundesagentur für Arbeit, 2004. Arbeitsmarkt 2003. Amtliche Nachrichten der Bundesagentur für Arbeit.

Card, D., 2009. Immigration and inequality. CReAM Discussion Paper 07/09. 
Chiswick, B.R., Cohen, Y., Zach, T., 1997. The labor market status of immigrants: effects of the unemployment rate at arrival and duration of residence. Industrial and Labor Relations Review 50 (2), 289-303.

D'Amuri, F., Ottaviano, G., Peri, G., 2008. The labour market impact of immigration in Western Germany in the 1990's. CEPR Discussion Paper No. 6736.

Diamond, P., 1982. Aggregate demand management in search equilibrium. Journal of Political Economy 90(5), 881-894.

Dustmann, C., Weiss, Y., 2007. Return migration: theory and empirical evidence for the UK. British Journal of Industrial Economics 45 (2), 236-256.

Edin, P.A., LaLonde, R.J., Åslund, O., 2000. Emigration of immigrants and measures of immigrant assimilation: evidence from Sweden. Swedish Economic Policy Review 7, 163204.

Forni, M., Hallin, M., Lippi, M., Reichlin, L., 2000. The generalized dynamic-factor model: identification and estimation. Review of Economics and Statistics 82 (4), 540-554.

Funk, P., Vogel, T., 2004. Endogenous skill bias. Journal of Economic Dynamics and Control 28 (11), 2155-2193.

Gartner, H., 2004. Die Imputation von Löhnen oberhalb der Beitragsbemessungsgrenze in der IAB Beschäftigtenstatistik. Working Paper IAB, Nuremberg.

Griliches, Z., 1969. Capital-skill complementarity. Review of Economics and Statistics 51 (4), 465-468.

Hall, R., 2005. Employment fluctuations with equilibrium wage stickiness. American Economic Review 95 (1), 50-65.

Hoynes, H.W., 2000. The employment, earnings, and income of less skilled workers over the business cycle. In: Card, D., Blank, R.M. (Eds.), Finding Jobs - Work and Welfare Reform, chapter 1. Russell Sage Foundation, New York, pp. 23-71.

Husted, L., Nielsen, H.S., Rosholm, M., Smith, N., 2001. Employment and wage assimilation of male first-generation immigrants in Denmark. International Journal of Manpower 22 (1-2), 39-68.

Jaeger, D.A., 2007. Green cards and the location choices of immigrants in the United States, 1971-2000. Research in Labor Economics 27, 131-183. 
Krusell, P., Ohanian, L.E., Ríos-Rull, J.-V., Violante, G.L., 2000. Capital-skill complementarity and inequality: a macroeconomic analysis. Econometrica 68 (5), 1029-1053.

Lütkepohl, H., 2006. New Introduction to Multiple Time Series Analysis. Springer-Verlag, Berlin.

Manacorda, M., Manning, A., Wadsworth, J., 2006. The impact of immigration on the structure of male wages: theory and evidence from Britain. CReAM Discussion Paper No. $08 / 06$.

Mayr, K., Peri, G., 2008. Return migration as a channel of brain gain. NBER Working Paper 14039.

Mortensen, D., 1982. Property rights and efficiency in mating, racing, and related games. American Economic Review 72 (5), 968-979.

OECD, 2008. International Migration Outlook 2008.

Oezcan, V., 2004. Germany: immigration in transition. Social Science Centre Berlin, www.migrationinformation.org/Profiles/display.cfm?ID=235.

Ottaviano, G., Peri, G., 2006. Rethinking the effects of immigration on wages. NBER Working Paper 12497.

Pissarides, C., 1985. Short-run equilibrium dynamics of unemployment, vacancies, and real wages. American Economic Review 75 (4), 676-690.

Ravn, M.O., Uhlig, H., 2002. On adjusting the Hodrick-Prescott filter for the frequency of observations. Review of Economics and Statistics 84 (2), 371-376.

Saint-Paul, G., 1996. Dual Labor Markets: A Macroeconomic Perspective. MIT Press, Cambridge.

Shimer, R., 2005. The cyclical behavior of equilibrium unemployment and vacancies. American Economic Review 95 (1), 25-49.

Wheatley Price, S., 2001. The employment adjustment of male immigrants in England. Journal of Population Economics 14 (1), 193-220.

Yashiv, E., 2007. U.S. labor market dynamics revisited. Scandinavian Journal of Economics 109 (4), 779-806. 


\section{Appendix}

\section{Appendix 1: Data and Samples}

\section{The IABS}

The basis for our analysis of Germany is the Employment Subsample 1975-2001 which is made available by the Institute for Employment Research (IAB). This administrative data set comprises a 2 percent subsample of all wage earners and salaried employees subject to social security contributions in Germany. The data set does not include the self-employed, the military, and workers in the civil service, but does include public sector workers. Overall, around 77 percent of all workers in the German economy in 2001 were covered by the social security system (Bundesagentur für Arbeit, 2004). The data also include all unemployed individuals who receive unemployment compensation. ${ }^{11}$ The IABS does not include individuals that are out of the labour force. Because of the time period analysed, the numerous adjustment processes in the East German labour market after German unification in 1990 and the relatively small immigrant population (the immigrant concentration in East Germany is only about 2.5 percent in 2001 compared to more than 10 percent in West Germany) we focus on West Germany throughout, excluding Berlin. For a detailed description of the data set see Bender et al. (2000).

\section{The Sample}

The sample population for the analysis on Germany comprises all dependent employees as well as the registered unemployed. In order to avoid issues of differential labour market entries and early retirement, we restrict our sample to the population aged 25 to 54 . Throughout the analysis, we consider two labour market outcomes for Germany: the unemployment rate and gross daily wages. Some explanation is necessary with regard to the construction of our unemployment rate for West Germany. The IABS includes two groups of individuals: first, employees who are subject to social security contributions and, second, unemployed individuals who are recipients of official unemployment compensation.

${ }^{11}$ In 2001, 74.5 percent of unemployed individuals in West Germany received official unemployment compensation - mostly either unemployment benefits (Arbeitslosengeld) or unemployment assistance (Arbeitslosenhilfe) and are hence recorded in the IABS (Bundesagentur 2004). The remaining 25.5 percent are in most cases unemployed individuals whose entitlement for unemployment benefits has run out and who do not qualify for the means-tested unemployment assistance. 
Therefore, the rate of unemployment that can be derived using the IABS is the number of these unemployed over the total number of unemployed plus employees. The second important labour market outcome variable we use is the daily wage of full-time workers. The wage data are taken directly from the IABS and adjusted to real 1995 prices using the consumer price index for all private households. All wages (or log wages) are reported in Euros. Wage records in the IABS are top coded at the social security contribution ceiling. We impute wages above that ceiling using a tobit-based method suggested by Gartner (2004). In the empirical estimations, we include six age group shares (25-29, 30-34, 35-39, 40-44, 45$49,50-54$, using the first group as the reference group) and use West Germany's 10 federal states as our regional units.

\section{The British Labour Force Survey (LFS)}

Our analysis for the UK is based on the British and the Northern Ireland Labour Force Surveys (LFS). The British LFS is a survey of private households living in Great Britain, carried out by the Office for National Statistics (ONS), while the Northern Ireland Labour Force Survey is carried out by the Department of Finance and Personnel. Both surveys used to be conducted biannually from 1973 to 1983 and annually between 1984 and 1991. Since the spring quarter 1992 the survey in Britain is conducted each quarter and changed to a rotating panel, with individuals included in five consecutive waves of the survey. In Northern Ireland the quarterly LFS was only introduced in the winter quarter of 1994. Both the British and the Northern Ireland LFS collect data on a wide range of aspects of the labour market. Questions on earnings were not asked before the winter quarter of 1992/1993 in Great Britain and 1994/1995 in Northern Ireland.

\section{The Sample}

From 1981 onwards, the UK Labour Force Survey allows an assessment of unemployment status according to the ILO definition of unemployment. The ILO definition defines an individual as unemployed if he/she is without work during the reference period, but available for work and actively seeking work. Hence, in the LFS individuals who are actively seeking work but are not eligible for official unemployment compensation are counted as unemployed while the IABS does not cover this group of people at all. On the other hand, individuals who are not available for work or are not actively seeking employment but receive unemployment benefits are not included in the number of unemployed persons in the LFS, 
although they are in the IABS. ${ }^{12}$ In order to make unemployment rates in both Germany and the UK as closely comparable as possible in this analysis, we exclude the self-employed and people on government schemes from our analysis for the UK. The reported unemployment rates may therefore deviate slightly from the numbers in official publications. As pointed out earlier, from the winter quarter 1992/1993 (1994/1995) onwards, the LFS for Britain (Northern Ireland) also contains information on wages of employees. The LFS does not report earnings of self-employed people, which, however, does not pose further problems because we exclude the self-employed to improve the comparability of our UK results with those of Germany. Wage data used throughout the analysis are hourly wages in pounds sterling where prices are adjusted to 1995 prices using the consumer price index. In the empirical estimations, we include six age group shares (25-29, 30-34, 35-39, 40-44, 45-49, 50-54, using the first group as the reference group) and distinguish 11 regional units: the three constituent countries Wales, Scotland, and Northern Ireland, and the eight standard statistical regions in England - London, South East, South West, East Midlands, West Midlands, North, North East, and Yorkshire and the Humber.

${ }^{12}$ It should be noticed that a sizeable fraction of the German labour force above 55 falls under this category. Based on the ILO definition of unemployment these individuals would not be classified as unemployed. This is one reason why we restrict our analysis to individuals below the age of 55 . 
Appendix 2: Differential Response to Economic Shocks, Women [Table A1 here] 


\section{Appendix 3: Equilibrium Search}

This appendix discusses why the volatility of the value associated with a match increases with the hazard or separation rate. Given the link between the value of a match, job openings, employment, and hence unemployment, this also shows how the separation rate affects the volatility of unemployment rates.

The value the typical firm associates with a match, denoted by $J_{s}$, is given by the following recursive formula:

$$
J_{s}=z_{s}-w_{s}+\beta(1-\delta) \sum_{s^{\prime}} \pi_{s, s^{\prime}} \times J_{s^{\prime}}
$$

The notation used in this expression is as follows. Subscripts distinguish different states of the economy, $s \in S$, say phases of the business cycle. If the economy is in state $s$ the value of a match, $J_{s}$, is simply the difference between the worker's labour productivity, $z_{s}$, and his wage, $w_{s}$, plus the discounted sum of the expected value of the match in the periods to come. Here, $\delta$ denotes the separation rate of the labour type considered (thus $1-\delta$ is the survival probability), and $\beta$ is the discount rate. The terms $\pi_{s, s^{\prime}}$ denote transition probabilities from (current) state $s$ to (future) state $s^{\prime}$.

For convenience suppose that the set of different states $S$ is finite. Then, using (A1), the value firms associate with a match in each state $s$ is (in matrix notation)

$$
\mathbf{J}=\left[\mathbf{I}+\beta(1-\delta) \boldsymbol{\Pi}+\beta^{2}(1-\delta)^{2} \boldsymbol{\Pi}^{2}+\ldots \mid \times(\mathbf{z}-\mathbf{w})\right.
$$

As long as wages ( $\mathbf{w})$ do not perfectly correlate with labour productivity ( $\mathbf{z}$ ), so that the firm's match surplus $\mathbf{z}-\mathbf{w}$ is not identical in each state, this expression illustrates how the hazard rate $\delta$ affects the volatility of the firm's value of a match $(\mathbf{J}) .^{13}$

${ }^{13}$ In most models of the DMP type wages are determined by the standard Nash bargaining solutions. Wages in these DMP models fluctuate with labour productivity over the business cycle because threat points adjust to the state of the cycle, implying a somewhat dampened oscillation of the unemployment rate. Shimer (2005) and Hall (2005) have recently criticised that the standard DMP model predicts a too high volatility of wages and too low cyclicality of unemployment rates. To remedy this deficiency, and in light of the fact that there is no economic imperative that leads us to prefer a particular bargaining solution, Hall (2005) proposed to assume that wages are constant (for all $s$ ). He shows that this is an equilibrium outcome as long as the constant wage satisfies certain boundary conditions, which ensures that workers always have an incentive to offer labour 
Notice that row elements of the matrix $\Pi=\left\lfloor\pi_{s, s^{\prime}}\right\rfloor$ sum to unity which also holds for all higher powers of $\boldsymbol{\Pi}$. Let the transition matrix $\boldsymbol{\Pi}^{T}$ be irreducible and aperiodic (i.e. ergodic). Then $\boldsymbol{\Pi z}$ is a vector consisting of weighted averages of the elements of $\mathbf{z}$, the vector $\Pi^{2} \mathbf{z}$ a vector of weighted averages of the averages and so on. In particular, $\Pi^{k} \mathbf{z} \rightarrow\left[\boldsymbol{\pi}^{*}\right]^{T} \mathbf{z} \underline{\mathbf{1}}$ as $k \rightarrow \infty$ where $\boldsymbol{\pi}^{*}$ is the stationary distribution with respect to $\boldsymbol{\Pi}^{T}$, implying that the greater the power of $\boldsymbol{\Pi}$, the more similar are the elements of the sum of the right-hand side of (A2). It is hence intuitive that the distance between the extreme elements of the vector $\mathbf{J}$, say $J_{s_{\max }} \equiv \max _{s} J_{s} \quad$ and $J_{s_{\min }} \equiv \min _{s} J_{s}$, and the unconditional expectation of $J_{s}$, $\left[\boldsymbol{\pi}^{*}\right]^{T} \mathbf{z} /(1-\beta(1-\delta))$, decreases as the survival probability $1-\delta$ increases.

To be more specific, let us study the peak-to-peak amplitude of firms' value of a match, $J_{s_{\max }} / J_{s_{\min }}$. Notice that each element of the vector $[1-\beta(1-\delta)] \times\left[\sum_{k \geq 0} \beta^{k}(1-\delta)^{k} \boldsymbol{\Pi}^{k}\right](\mathbf{z}-\mathbf{w})$ is a weighted average of $\mathbf{z}-\mathbf{w}$ since elements of each row of $[1-\beta(1-\delta)] \times\left[\sum_{k \geq 0} \beta^{k}(1-\delta)^{k} \Pi^{k}\right]$ are nonnegative and sum to unity. To simplify the argument, we assume that the averaging or mixing effect is sufficiently strong such that $[\mathbf{z}-\mathbf{w}]_{s_{\max }} \geq\left[\boldsymbol{\Pi}^{k}(\mathbf{z}-\mathbf{w})\right]_{s_{\max }}$ for all $k \in N_{0}$. Then an increase in $1-\delta$ always puts a higher weight on smaller elements of the series $\sum_{k \geq 0} \beta^{k}(1-\delta)^{k} \mathbf{\Pi}^{k}(\mathbf{z}-\mathbf{w})$. Hence, the larger $1-\delta$, the smaller the expression $[1-\beta(1-\delta)] \times J_{s_{\max }}$. By the same token, let $[\mathbf{z}-\mathbf{w}]_{s_{\min }} \leq\left[\boldsymbol{\Pi}^{k}(\mathbf{z}-\mathbf{w})\right]_{s_{\min }}$ for all $k \in N_{0}$. Then, the greater $1-\delta$, the larger $[1-\beta(1-\delta)] \times J_{s_{\min }}$. This implies that the ratio $J_{s_{\max }} / J_{s_{\min }}$ decreases in the survival probability $1-\delta$ or, equivalently, increases in the separation rate $\delta$. Thus, the higher the survival probability, the less $J_{s}$ oscillates around its mean. This example shows that the smaller the separation rate, the less sensitive the firms' value of a match (and hence the number of newly created jobs in each period) is to the state of the business cycle.

and firms always have an incentive to hire the worker. Although not crucial for our argument, the reader may follow Hall and assume that wages are constant—while respecting Hall's boundaries. 
Table 1: Individual characteristics in 2001

\begin{tabular}{|c|c|c|c|c|c|c|c|c|}
\hline & \multicolumn{4}{|c|}{ Germany } & \multicolumn{4}{|c|}{ UK } \\
\hline & Natives & Immigrants & OECD & Non-OECD & Natives & Immigrants & OECD & Non-OECD \\
\hline \multicolumn{9}{|l|}{ Education } \\
\hline Low education & 16.3 & 53.1 & 52.9 & 53.7 & 14.5 & 18.3 & 12.0 & 21.6 \\
\hline Intermediate education & 73.4 & 41.0 & 41.2 & 40.6 & 58.5 & 52.8 & 56.7 & 50.7 \\
\hline High education & 10.2 & 5.8 & 5.9 & 5.7 & 27.0 & 28.9 & 31.2 & 27.7 \\
\hline Mean age & 39.3 & 38.0 & 37.8 & 38.4 & 39.5 & 38.4 & 37.6 & 38.8 \\
\hline \multicolumn{9}{|l|}{ Mean log wage } \\
\hline Men & $\begin{array}{c}4.45 \\
(0.37)\end{array}$ & $\begin{array}{c}4.23 \\
(0.43)\end{array}$ & $\begin{array}{c}4.28 \\
(0.40)\end{array}$ & $\begin{array}{l}4.12 \\
(0.46)\end{array}$ & $\begin{array}{l}2.18 \\
(0.54)\end{array}$ & $\begin{array}{l}2.21 \\
(0.65)\end{array}$ & $\begin{array}{l}2.35 \\
(0.64)\end{array}$ & $\begin{array}{l}2.11 \\
(0.64)\end{array}$ \\
\hline Women & $\begin{array}{c}4.15 \\
(0.49)\end{array}$ & $\begin{array}{l}4.01 \\
(0.50)\end{array}$ & $\begin{array}{c}4.02 \\
(0.51)\end{array}$ & $\begin{array}{l}3.98 \\
(0.48)\end{array}$ & $\begin{array}{l}1.91 \\
(0.52)\end{array}$ & $\begin{array}{l}2.05 \\
(0.56)\end{array}$ & $\begin{array}{l}2.11 \\
(0.59)\end{array}$ & $\begin{array}{l}2.01 \\
(0.54)\end{array}$ \\
\hline \multicolumn{9}{|l|}{ Unemployment rate } \\
\hline Men & 6.8 & 11.8 & 11.1 & 13.5 & 4.6 & 8.0 & 4.5 & 10.0 \\
\hline Women & 5.8 & 11.1 & 12.4 & 8.7 & 3.6 & 6.5 & 4.7 & 7.7 \\
\hline $\begin{array}{l}\text { Regional concentration } \\
\text { (Herfindahl Index) }\end{array}$ & 0.08 & 0.11 & 0.11 & 0.10 & 0.02 & 0.15 & 0.11 & 0.18 \\
\hline
\end{tabular}

Source: IABS and LFS. Based on individuals aged 25 to 54 . Mean log wage refers to the mean log daily wage in Germany (in $1995 €$ ) and the mean log hourly wage in the UK (in $1995 £$ ). Standard deviations for the log wage are given in parenthesis. See Appendix 1 for the definitions of unemployment rates in both countries. 
Figure 1: GDP growth and unemployment rates

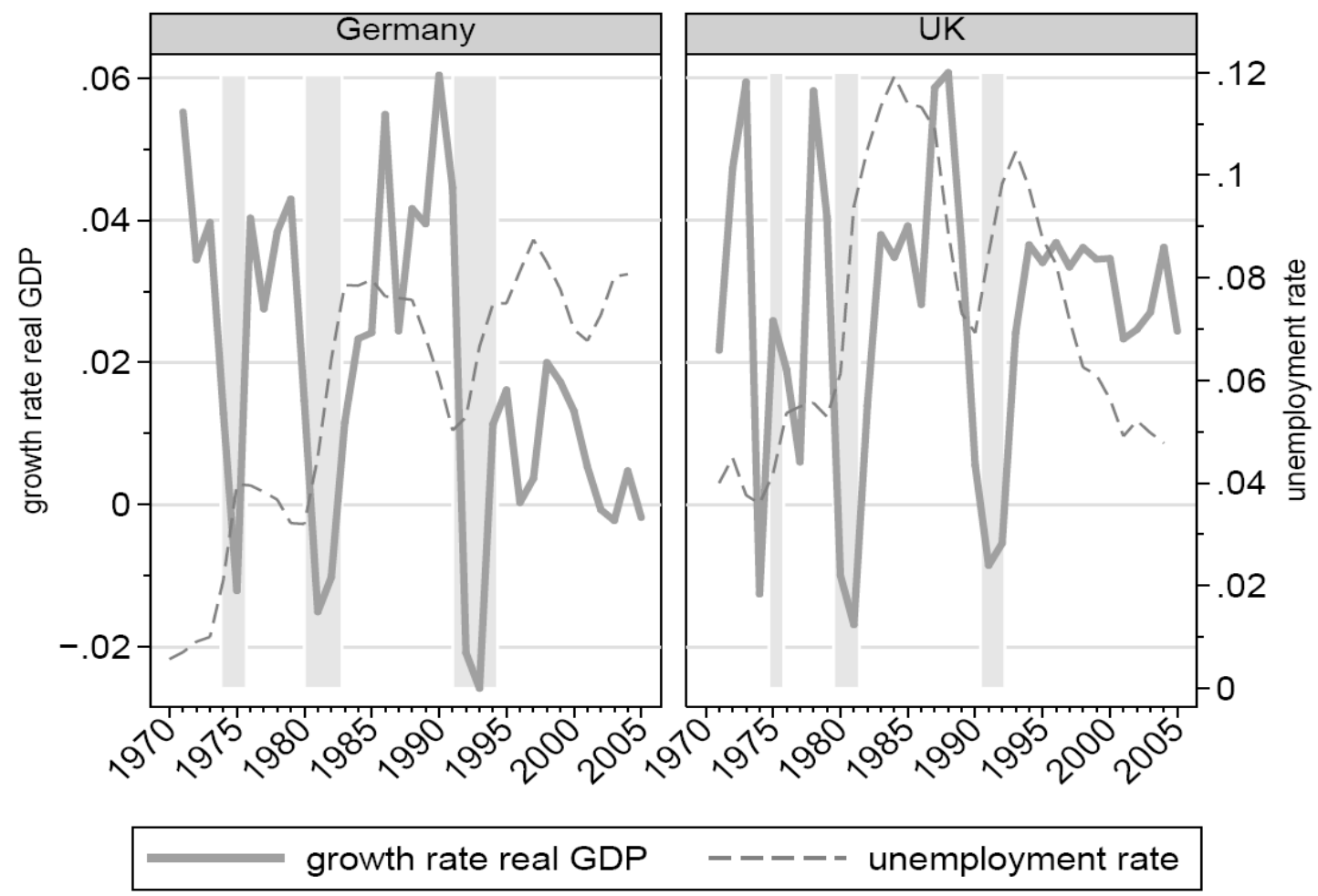

Source: Volkswirtschaftliche Gesamtrechnung der Länder (VGR d L) for Germany; OECD for the UK. Dating of recessions (indicated by the shades) by the Economic Cycle Research Institute. Data for Germany only refer to West Germany, excluding Berlin. 
Figure 2: Conditional unemployment rate differentials
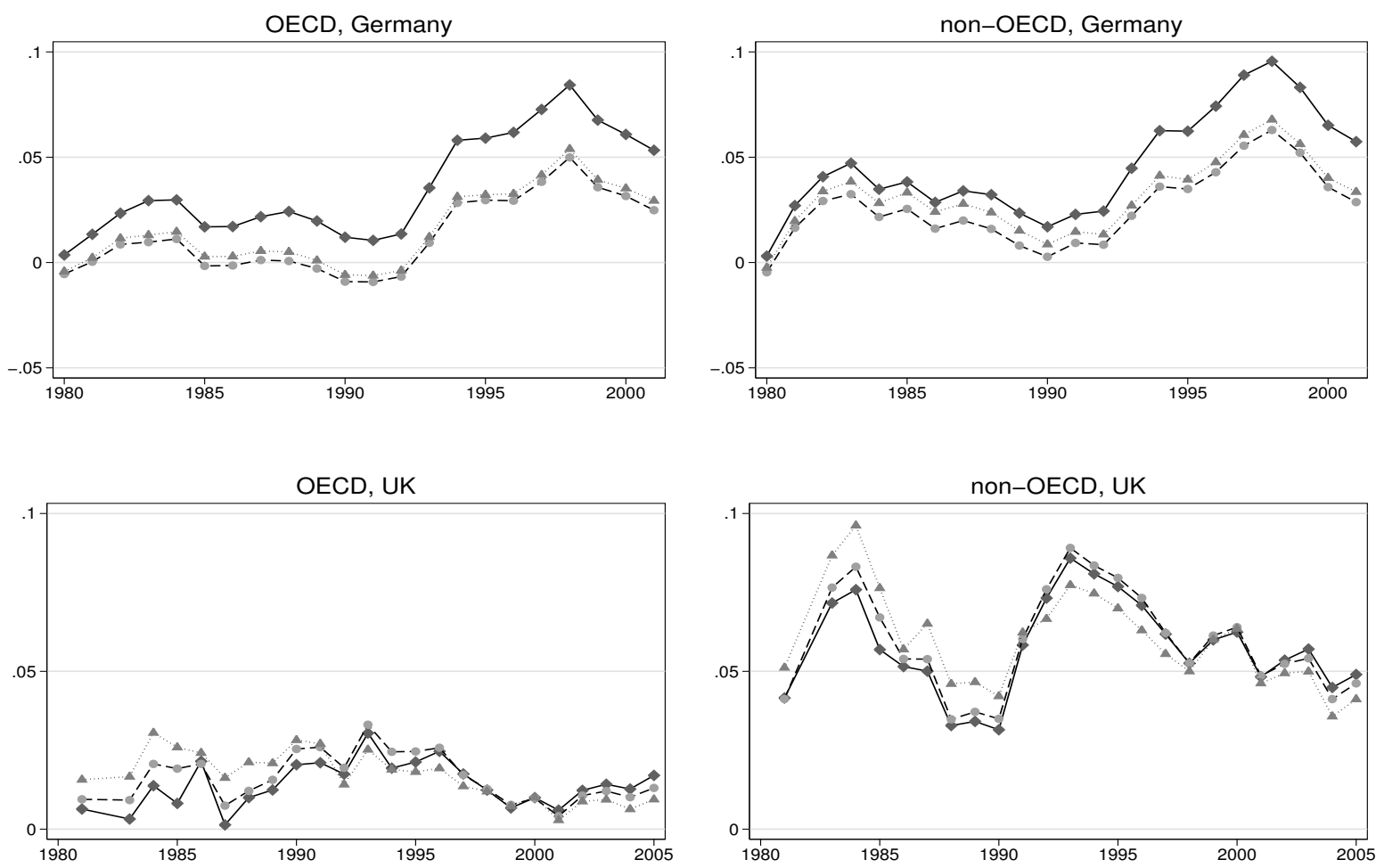

- gender controls $\quad-\odot-$ gender, age, education controls $\quad \cdots . . .$. gender, age, education, region controls

Source: IABS and LFS, individuals aged 25-54. 
Figure 3: Conditional log wage differentials
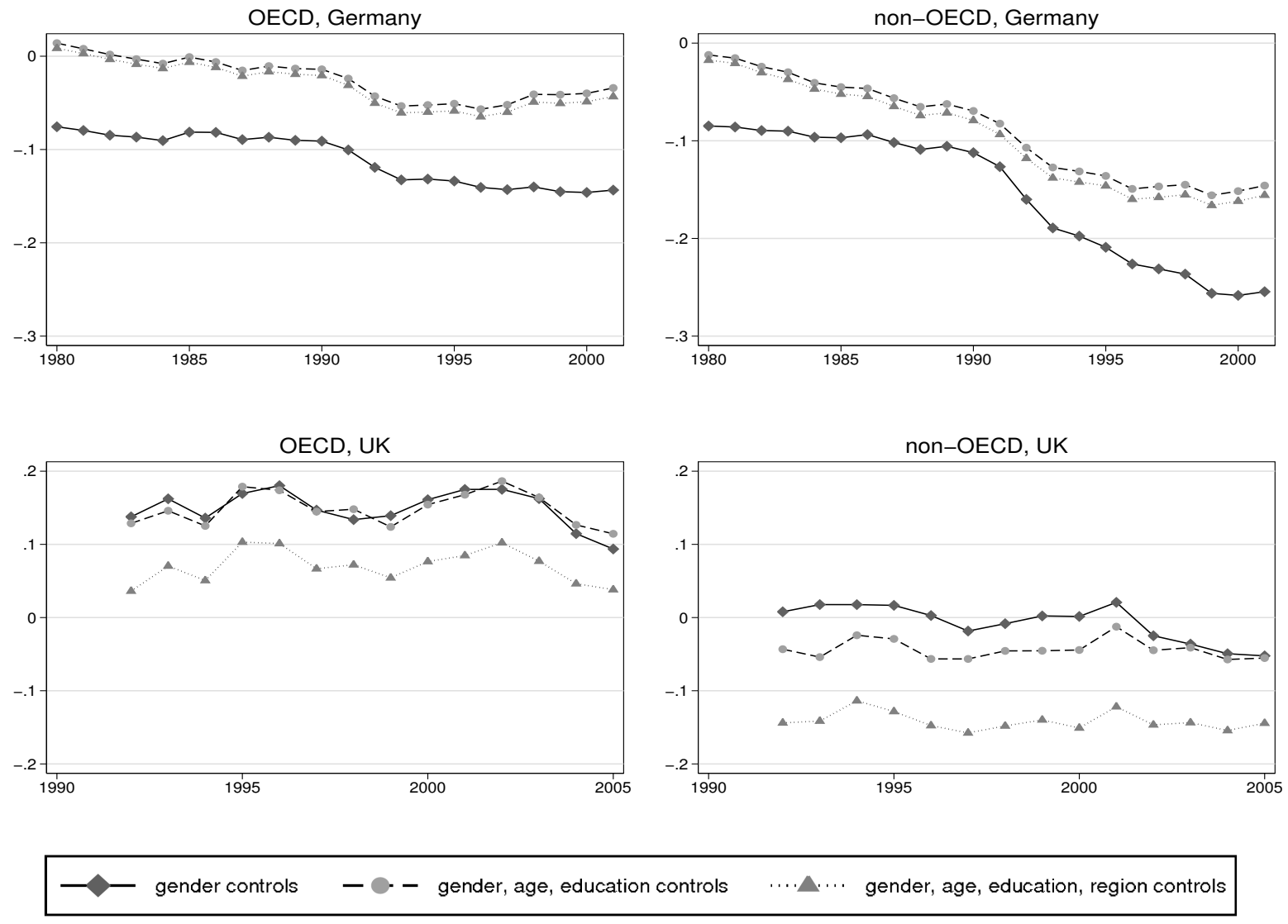

Source: IABS and LFS, individuals aged 25-54. 
Table 2: Differential response to economic shocks, men

\begin{tabular}{|c|c|c|c|c|}
\hline \multirow[t]{3}{*}{ IABS/LFS (individuals aged 25-54) } & \multicolumn{2}{|c|}{ Unemployment Rate } & \multicolumn{2}{|c|}{ Log Wages } \\
\hline & (1) & $(2)$ & (3) & $(4)$ \\
\hline & Germany & UK & Germany & UK \\
\hline \multicolumn{5}{|l|}{ High education } \\
\hline Non-immigrant & 1 & 1 & 1 & 1 \\
\hline \multirow[t]{2}{*}{ OECD } & 1.789 & 1.470 & 1.097 & 1.387 \\
\hline & $(0.683)$ & $(0.290)$ & $(0.225)$ & $(0.921)$ \\
\hline \multirow[t]{2}{*}{ non-OECD } & 1.592 & $1.979^{*}+$ & $-1.702^{*}+$ & 0.824 \\
\hline & $(1.277)$ & $(0.225)$ & $(0.617)$ & $(0.361)$ \\
\hline \multicolumn{5}{|l|}{ Intermediate education } \\
\hline \multirow[t]{2}{*}{ Non-immigrant } & $2.412^{*}$ & $2.932^{*}$ & $1.386^{*}$ & 0.885 \\
\hline & $(0.494)$ & $(0.227)$ & $(0.090)$ & $(0.073)$ \\
\hline \multirow[t]{2}{*}{ OECD } & $4.162^{*}+$ & $2.950^{*}$ & $1.038+$ & 1.543 \\
\hline & $(0.962)$ & $(0.626)$ & $(0.133)$ & $(0.469)$ \\
\hline \multirow[t]{2}{*}{ non-OECD } & $5.720^{*}+$ & $4.193^{*}+$ & 1.294 & $1.534^{*}+$ \\
\hline & $(1.436)$ & $(0.326)$ & $(0.156)$ & $(0.249)$ \\
\hline \multicolumn{5}{|l|}{ Low education } \\
\hline \multirow[t]{2}{*}{ Non-immigrant } & $4.515^{*}$ & $3.893^{*}$ & $1.873^{*}$ & 0.934 \\
\hline & $(0.920)$ & $(0.300)$ & $(0.118)$ & $(0.125)$ \\
\hline \multirow[t]{2}{*}{ OECD } & $4.724^{*}$ & $5.119^{*}$ & $1.693^{*}$ & 1.249 \\
\hline & $(0.959)$ & (1.353) & $(0.138)$ & (1.120) \\
\hline \multirow[t]{2}{*}{ non-OECD } & $6.697^{*}+$ & $5.537^{*}$ & $1.461^{*}+$ & 1.062 \\
\hline & $(1.367)$ & (1.025) & $(0.210)$ & (0.478) \\
\hline Observations & 3,409 & 2,372 & 3,408 & 1,167 \\
\hline $\mathrm{R} 2$ & 0.631 & 0.564 & 0.634 & 0.5 \\
\hline
\end{tabular}

Note: Regression estimated using nonlinear weighted least squares, using the cells' population as the weights. The sample covers men and women aged 25-54 from 1982 to 2001 for Germany and from 1981 to 2005 for the UK. In the case of the UK, two years are pooled together such that for the unemployment rates we generate two-year intervals starting with years 1981, 1983 and so on. For the wage regression for the UK, data is only available from the fourth quarter of 1992 onwards. We therefore form two-year clusters 1992/1993, 1994/1995 and so on. As the regional unit we use the ten West German states ("Länder") and for the UK the eleven regional units listed in the text. For details on the construction of the outcome variables, see Appendix 1. Robust standard errors are in parentheses and clustered on the group/education/region level. A $\left(^{*}\right)$ indicates the parameter is different from one at the 5 percent level. A (+) indicates that the parameter is different from the corresponding parameter of the native group at the 5 percent level. 
Table A1: Differential response to economic shocks, women

\begin{tabular}{|c|c|c|c|c|}
\hline \multirow[t]{3}{*}{ IABS/LFS (individuals aged 25-54) } & \multicolumn{2}{|c|}{ Unemployment Rate } & \multicolumn{2}{|c|}{ Log Wages } \\
\hline & (1) & (2) & (3) & (4) \\
\hline & Germany & UK & Germany & UK \\
\hline \multicolumn{5}{|l|}{ High education } \\
\hline \multirow[t]{2}{*}{ Non-immigrant } & 1.495 & $0.613^{*}$ & $1.350^{*}$ & 0.887 \\
\hline & $(0.580)$ & $(0.121)$ & $(0.166)$ & $(0.099)$ \\
\hline \multirow[t]{2}{*}{ OECD } & 2.339 & 0.488 & 0.474 & 1.303 \\
\hline & $(1.375)$ & $(0.296)$ & $(0.702)$ & $(0.463)$ \\
\hline \multirow[t]{2}{*}{ non-OECD } & 0.015 & $0.221^{*}$ & -0.687 & 0.971 \\
\hline & $(1.402)$ & $(0.373)$ & $(1.242)$ & $(0.449)$ \\
\hline \multicolumn{5}{|l|}{ Intermediate education } \\
\hline \multirow[t]{2}{*}{ Non-immigrant } & 1.378 & 1.036 & $1.250^{*}$ & 1.067 \\
\hline & $(0.291)$ & $(0.119)$ & $(0.085)$ & $(0.076)$ \\
\hline \multirow[t]{2}{*}{ OECD } & $2.374^{*}+$ & 1.141 & 1.095 & 1.017 \\
\hline & $(0.591)$ & $(0.252)$ & $(0.207)$ & $(0.335)$ \\
\hline \multirow[t]{2}{*}{ non-OECD } & $2.236^{*}$ & $2.141^{*}+$ & 1.353 & 1.412 \\
\hline & $(0.606)$ & $(0.243)$ & $(0.372)$ & $(0.361)$ \\
\hline \multicolumn{5}{|l|}{ Low education } \\
\hline \multirow[t]{2}{*}{ Non-immigrant } & $2.593^{*}$ & $2.057^{\star}$ & $1.774^{*}$ & 1.054 \\
\hline & $(0.543)$ & $(0.235)$ & $(0.117)$ & $(0.108)$ \\
\hline \multirow[t]{2}{*}{ OECD } & $4.098^{*}+$ & $0.689+$ & $1.514^{\star}$ & $1.844^{*}+$ \\
\hline & $(1.000)$ & $(0.548)$ & $(0.170)$ & $(0.365)$ \\
\hline \multirow[t]{2}{*}{ non-OECD } & 2.499 & $3.176^{*}+$ & $0.803+$ & 1.253 \\
\hline & $(0.843)$ & $(0.557)$ & $(0.141)$ & $(0.508)$ \\
\hline Observations & 3,409 & 2,372 & 3,408 & 1,167 \\
\hline $\mathrm{R} 2$ & 0.631 & 0.564 & 0.634 & 0.500 \\
\hline
\end{tabular}

Note: See Table 2. 


\section{Table 3: Differential response to economic shocks, robustness checks, men}

\begin{tabular}{|c|c|c|c|c|}
\hline \multirow[t]{4}{*}{ IABS/LFS (individuals aged 25-54) } & \multicolumn{4}{|c|}{ Unemployment Rate } \\
\hline & \multicolumn{2}{|c|}{ Balanced panel } & \multicolumn{2}{|c|}{ Using HP-filtered GDP } \\
\hline & (1) & (2) & (3) & (4) \\
\hline & Germany & UK & Germany & UK \\
\hline \multicolumn{5}{|l|}{ High education } \\
\hline Non-immigrant & 1 & 1 & 1 & 1 \\
\hline \multirow[t]{2}{*}{ OECD } & 0.743 & $1.889^{*}+$ & 1.411 & 2.590 \\
\hline & $(0.453)$ & $(0.431)$ & $(1.257)$ & $(1.708)$ \\
\hline \multirow[t]{2}{*}{ non-OECD } & 1.604 & 1.514 & 4.263 & 1.574 \\
\hline & $(1.467)$ & $(0.293)$ & $(2.408)$ & $(0.584)$ \\
\hline \multicolumn{5}{|l|}{ Intermediate education } \\
\hline \multirow[t]{2}{*}{ Non-immigrant } & $2.401^{*}$ & $3.000^{*}$ & 1.374 & 1.709 \\
\hline & $(0.516)$ & $(0.246)$ & $(0.695)$ & $(0.610)$ \\
\hline \multirow[t]{2}{*}{ OECD } & $3.222^{*}$ & $3.865^{*}$ & 4.561 & $3.637^{*}+$ \\
\hline & $(0.818)$ & $(0.842)$ & $(2.233)$ & $(1.232)$ \\
\hline \multirow[t]{2}{*}{ non-OECD } & $5.556^{\star}+$ & $3.208^{*}$ & 4.526 & 2.178 \\
\hline & $(1.529)$ & $(0.362)$ & (2.373) & (1.025) \\
\hline \multicolumn{5}{|l|}{ Low education } \\
\hline \multirow[t]{2}{*}{ Non-immigrant } & $4.525^{\star}$ & $4.005^{*}$ & 4.292 & $4.526^{*}$ \\
\hline & $(0.968)$ & $(0.319)$ & (2.065) & (1.564) \\
\hline \multirow[t]{2}{*}{ OECD } & $3.275^{\star}+$ & $5.388^{*}$ & 5.529 & 4.925 \\
\hline & $(0.715)$ & $(0.942)$ & $(2.676)$ & (2.285) \\
\hline \multirow[t]{2}{*}{ non-OECD } & $5.312^{*}$ & $5.702^{*}$ & 7.289 & $6.628^{*}$ \\
\hline & $(1.293)$ & $(1.031)$ & (3.479) & $(2.842)$ \\
\hline Observations & 3,330 & 2,321 & 3,409 & 2,192 \\
\hline $\mathrm{R} 2$ & 0.660 & 0.574 & 0.238 & 0.273 \\
\hline
\end{tabular}

Note: See Table 2. Sample in column (1) includes only those foreign citizens in Germany who are already observed in the data in 1982. Sample in column (2) includes only those foreign born individuals who report having immigrated to the UK in or before 1981. Regressions in columns (3) and (4) are estimated using ordinary least squares. Entries show coefficients of the interactions of HP-filtered regional GDP with each education/nationality group. $A\left(^{*}\right)$ indicates the parameter is different from one at the 5 percent level. A (+) indicates that the parameter is different from the corresponding parameter of the native group at the 5 percent level. 


\section{Table 4: Differential response to economic shocks, allowing for asymmetries in economic upturns and downturns, men}

\begin{tabular}{|c|c|c|c|c|}
\hline \multirow[t]{4}{*}{ IABS/LFS (individuals aged 25-54) } & \multicolumn{4}{|c|}{ Unemployment Rate } \\
\hline & (1) & (2) & (3) & (4) \\
\hline & \multirow[b]{2}{*}{ Group-specific effect } & nany & \multicolumn{2}{|c|}{ UK } \\
\hline & & $\begin{array}{l}\text { Group-specific effect } \\
\text { in economic downturn }\end{array}$ & Group-specific effect & $\begin{array}{l}\text { Group-specific effect } \\
\text { in economic downturn }\end{array}$ \\
\hline \multicolumn{5}{|l|}{ High education } \\
\hline Non-immigrant & 1 & 0 & 1 & 0 \\
\hline \multirow[t]{2}{*}{ OECD } & 0.570 & 1.932 & 1.185 & 0.529 \\
\hline & $(1.019)$ & $(1.819)$ & $(0.621)$ & $(1.087)$ \\
\hline \multirow[t]{2}{*}{ non-OECD } & -1.539 & $4.639+$ & 2.266 & -0.455 \\
\hline & $(3.386)$ & $(3.320)$ & $(0.653)$ & $(0.937)$ \\
\hline \multicolumn{5}{|l|}{ Intermediate education } \\
\hline \multirow[t]{2}{*}{ Non-immigrant } & 2.977 & -0.816 & $2.847^{*}$ & -0.166 \\
\hline & $(1.399)$ & $(1.605)$ & $(0.461)$ & $(0.614)$ \\
\hline \multirow[t]{2}{*}{ OECD } & 3.279 & $1.363+$ & $4.397^{*}+$ & $-2.229^{*}+$ \\
\hline & $(1.646)$ & $(2.111)$ & $(0.785)$ & $(1.036)$ \\
\hline \multirow[t]{2}{*}{ non-OECD } & 8.285 & -3.757 & $5.524^{*}+$ & -2.044 \\
\hline & (3.922) & $(4.521)$ & $(0.936)$ & $(1.322)$ \\
\hline \multicolumn{5}{|l|}{ Low education } \\
\hline \multirow[t]{2}{*}{ Non-immigrant } & 5.209 & -0.972 & $6.053^{\star}$ & $-3.118^{*}$ \\
\hline & $(2.458)$ & $(2.867)$ & $(0.993)$ & $(1.314)$ \\
\hline \multirow[t]{2}{*}{ OECD } & 4.673 & $0.091+$ & $11.406^{*}+$ & $-8.999^{\star}+$ \\
\hline & $(2.219)$ & $(2.702)$ & $(2.205)$ & $(2.180)$ \\
\hline \multirow[t]{2}{*}{ non-OECD } & 8.355 & $-2.379+$ & $7.508^{*}$ & -2.976 \\
\hline & (3.992) & $(4.634)$ & $(2.164)$ & $(2.300)$ \\
\hline Observations & \multicolumn{2}{|c|}{3,409} & \multicolumn{2}{|c|}{2,372} \\
\hline R2 & \multicolumn{2}{|c|}{0.633} & \multicolumn{2}{|c|}{0.570} \\
\hline
\end{tabular}

Note: See Table 2. Entries in columns (1) and (3) show the parameter estimates for periods of economic expansion while entries in columns (2) and (4) show the additional effect during periods of economic contraction. Periods indexed as economic downturns are 1982-1983 and 1993-1997 in Germany and 1981-1986 and 19911992 in the UK. In columns (1) and (3), a $\left(^{*}\right)$ indicates the parameter is different from one at the 5 percent level and in columns (2) and (4) that it is different from zero. In columns (1) and (3), a (+) indicates that the parameter is different from the corresponding parameter of the native group at the 5 percent level. In columns (2) and (4) we test whether the overall effect in an economic downturn for each immigrant group - the sum of the parameters in both columns - is different from the overall effect in an economic downturn of the corresponding native group, with a (+) indicating significance at the 5 percent level. 


\section{Table 5: Job separation, men}

\begin{tabular}{|c|c|c|c|}
\hline IABS (individuals aged 25-54) & Non-immigrant & OECD & Non-OECD \\
\hline & \multicolumn{3}{|c|}{ Panel A: Kaplan-Meier survival probabilities } \\
\hline \multicolumn{4}{|l|}{ High education } \\
\hline 1 year & 0.768 & 0.741 & 0.691 \\
\hline 3 years & 0.515 & 0.437 & 0.399 \\
\hline 5 years & 0.368 & 0.281 & 0.285 \\
\hline 10 years & 0.204 & 0.148 & 0.142 \\
\hline \multicolumn{4}{|l|}{ Intermediate education } \\
\hline 1 year & 0.717 & 0.642 & 0.595 \\
\hline 3 years & 0.494 & 0.393 & 0.345 \\
\hline 5 years & 0.380 & 0.277 & 0.239 \\
\hline 10 years & 0.229 & 0.149 & 0.119 \\
\hline \multicolumn{4}{|l|}{ Low education } \\
\hline 1 year & 0.639 & 0.636 & 0.566 \\
\hline 3 years & 0.415 & 0.420 & 0.343 \\
\hline 5 years & 0.315 & 0.316 & 0.222 \\
\hline \multirow[t]{2}{*}{10 years } & 0.182 & 0.185 & 0.114 \\
\hline & \multicolumn{3}{|c|}{ Panel B: Cox proportional hazard ratios } \\
\hline \multirow[t]{2}{*}{ High education } & 1 & $1.190^{*}$ & $1.311^{*}$ \\
\hline & & $(0.044)$ & $(0.070)$ \\
\hline \multirow[t]{2}{*}{ Intermediate education } & 1 & $1.248^{*}$ & $1.344^{*}$ \\
\hline & & $(0.016)$ & $(0.025)$ \\
\hline \multirow[t]{2}{*}{ Low education } & 1 & 0.994 & $1.187^{*}$ \\
\hline & & $(0.014)$ & $(0.020)$ \\
\hline
\end{tabular}

Note: Entries in Panel A are non-parametric Kaplan-Meier survival probabilities of staying in a job. Entries in Panel B show Cox proportional hazard ratios of leaving a job relative to non-immigrants, estimated separately for each education group. Estimates are based on a 30 percent random sample of the IABS and, in Panel B, are stratified by age group and year. $A\left({ }^{*}\right)$ indicates that the hazard ratio is different from 1 at the 5 percent level. 